\title{
KC法を用いた新しいSuper-Resolution PIVの提案 A PROPOSAL OF A NEW SUPER-RESOLUTION PIV BY USING THE KC METHOD
}

\author{
竹原幸生 $1 \cdot$ R. J. Adrian ${ }^{2}$ ・ 江藤剛治 ${ }^{3}$ \\ Kohsei TAKEHARA, R. J. ADRIAN and Takeharu ETOH \\ 1正会員 博 (工) 近畿大学講師 理工学部土木工学科（テ577-8502 東大阪市小若江3-4-1) \\ ${ }^{2}$ Member of ASME, Ph.D., University of Illinois at Urbana-Champaign \\ 3 正会員 工博 近畿大学教授 理工学部土木工学科（テ577-8502 東大阪市小若江3-4-1）
}

\begin{abstract}
A new super-resolution PIV is proposed. The proposed super-resolution method consists of the standard correlation PIV, the Particle Mask Correlation method (PMC method), and Kalman filter $\chi^{2}$-test method (KC method). The present super-resolution PIV is referred as to the "super-resolution KC method".

Performance of the super resolution $\mathrm{KC}$ method is examined by the Monte-Calro simulation. The superresolution $\mathrm{KC}$ method is also applied to the measurement of the two kinds of flow fields, of which images are captured by the Double-Pulse/Single-Image method and Single-Pulse/Double-Image method, respectively.
\end{abstract}

Key Words : Super-Resolution PIV, KC method, Particle Mask Correlation Method

\section{1. はじめに}

粒子画像速度計測法(Particle Imaging Velocimetry, PIV) は，流れ中のトレーサー粒子の移動を画像により計測し， 速度場を推定する方法である。PIVの特長の 1 つは，こ れまでの点計測では困難であった瞬時の空間流速分布を 計測できることであり，新たな流れ場の理解が期待され る。すでにいくつかの新たな知見も得られ始めているり。 これまで，種々のPIVアルゴリズムが提条されており， 現在，性能向上のため改良が続けられている。PIV技術 の開発においては，精度をある程度犠牲にしてリアルタ イムで計測できる技術と，解析時間をある程度犠牲にし て数值計算結果に匹敵，もしくはそれ以上の精度で計測 できる技術の 2 つ方向性がある。著者らは後者の立場 に立ち, 開発を行ってきた。今後, より高い時間解像度, 空間解像度の計測技術の開発を目的としている。

時間解像度を上げるには，サンプリング周波数を増加 させるしかない。これを解決する方法として高速ビデオ カメラの開発が必要である2)

本研究では, 高空間解像度PIVの開発を目的としてい る。空間解像度を上げる方法としては，ビデオカメラ自 体の解像度を上げるだけでは，PIVの解像度を上げるこ とができない。画像中の多数の粒子を精度良く自動追跡 するアルゴリズムが必要となる。

PIVには大きく分けて 2 つ方法がある。1つの方法 は, トレーサー粒子の分布パターンの移動を求める
PMV(Pattern Matching Velocimetry)であり，もう1つは， 各トレーサー粒子を追跡するPTV(Particle Tracking Velocimetry)である。PMVの代表的なものは相関法であ り，すでに標準的なソフトとして市販化されている。 PTVに関しても，いくつかの方法が提案されており，一 部市販化されているものもある。

PMVの長所の 1 つは，2時刻間の画像から流速を求め ることができることである。Double-Pulse/Single-Image, もしくはSingle-Pusle/Double-Imageやら流速場を求めるこ とができる。PTVでも 2 時刻間で対応付け可能なアルゴ リズムも提案されているが，粒子数が増加すると誤対応 の確率が増す。誤対応の確率を減少させるには，同一粒 子の対応付けに用いる画像数を増加させるしかない。

一方, PTVの長所として, PMVに比べて空間解像度が 高いことが上げられる。PMVは検索領域内にある数個 〜十数個の粒子の平均移動量を計測しているものであり， 個々の粒子の移動を求めたPTVに比べて原理的に解像度 が低い。PMVでも，検索領域をオーバーラップするこ とで，見かけ上，多数のベクトルを得ることができるが， 実質的な空間解像度は検索領域のサイズで決まる。

Keaneら ${ }^{3)}$ は，それぞれの長所を組み合わせたSuperResolution 法を提案している。Super-Resolution法では, まずPMVにより粗い格子点上の流速べクトルを求め, その格子点の速度情報を元に各粒子に速度を内挿し， PTVで 2 時刻間の同一粒子の同定を行う。これにより， 2 時刻間で粒子を追跡することができ，解像度の高い流 
速場の計測が可能となる。

Keaneら ${ }^{3)}$ の方法では，後述のように，PTVの粒子同定 のアルゴリズムに問題がある。本研究では，第1,3著者 が提案しているカルマンフィルターと $\chi^{2}$ 検定を用いた

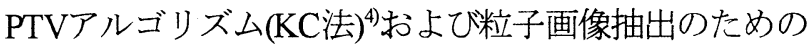
粒子マスク相関法(PMC法)方用い， Super-Resolution法 のPTV部分の改良を行った。また，提案された手法の性 能をシミュレーション画像により評価した。さらに, 実 際の流れ場計測に適用した。適用した画像はDoublePulse/Single-Image，およびSingle-Pusle/Double-Imageの 2 ケース行った。

\section{Super-Resolution法のアルゴリズム}

まず，Keaneらの提案したSuper-Resolution法の手順を 示す。

(1) 2 時刻の粒子画像に対して，標準の相関法により，粗 な格子点上の流速を求める。

(2)第 1 時刻の画像上から各粒子画像をピックアップし, 求めた格子点の流速を元に各粒子の速度を内挿する。

(3)各粒子の内挿された速度から，第 2 時刻の粒子位置を 推定する。

(4)第 1 時刻の粒子画像周りに粒子サイズと同等の検索画 像領域を設定し，その粒子画像に対応する第 2 時刻の 推定された粒子位置の周りにも，同じサイズの検索画 像領域を設け，相互相関値を計算する。

(5)相互相関值のピーク位置から各粒子の移動を求める。

彼らのSuper-Resolution法のPTV部分(手順(4)には以下

の上うな問題点がある。

(1)PTVにおける検索領域が小さいため, 相関法で流速を 求めるときの検索領域内で, 変形が粒子サイズ以上 になると計測できない。

(2)各粒子の対応付けの検索画像領域内に 2 つ上の候補 粒子がある場合に，同一粒子を識別できない。

問題点(1)および(2)は，お互いに競合関係にある。問 題点(1)でPTVにおける第 2 時刻の検索画像領域を大きく 寸れば，大きな流体変形に対しても計測可能となる。し かし，第2 時刻の検索画像領域を大きくすればするほど, その領域内に複数の粒子が含まれるようになり，問題点 (2)が顕在化してくる。

\section{KC法とPMC法によるSuper-Resolution法の改良}

カルマンフィルターと $x^{2}$ 検定を用いたPTVアルゴリ ズム $(\mathrm{KC} \text { 法 })^{4}$ ，および粒子画像抽出のための粒子マスク 相関法(PMC法) 学用いた新しいSuper-Resolution法を提 案する(以降，Super-Resolution KC法之呼ぶ)。

KC法はPTVのためのアルゴリズムとして提案された22。 カルマンフィルターにより，ある時刻の粒子情報粒子 位置, 速度ベクトル, 粒子画像サイズ, 粒子画像中心輝
度，等)をもとに，次時刻の粒子情報を予測する。予測 された粒子位置周りに検索領域を設け，その中に含まれ る実測粒子との対応付けを行う。予測された粒子情報と 検索領域内の数個の実測された粒子の情報から， $\chi^{2}$ 検 定を用いて同一粒子の同定を行う。

KC法は, KeaneらのPTV法と違い, はじめから検索領 域内に多数の侯補粒子が存在した場合を想定している。 $\mathrm{KC}$ 法では，同一粒子の対応付けを予測粒子位置と実測 粒子位置のみの関係で判断するのではなく, 粒子画像サ イズや中心輝度等の粒子情報の予測值と実測值との関係

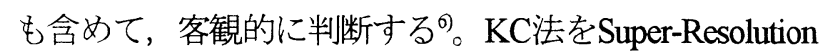
法のPTV部分に適用することにより，Keaneらの方法で 問題となった点を解消することができる。

PMC法は，粒子画像を画像中から効率よく抽出する ための方法である。1 個の粒子画像のテンプレート(粒 子マスクと呼ぶ)を作り, 得られた画像と粒子マスクと の相関を取る。画像中の各画素を中心に粒子マスクとの 相関值を計算し，相関值画像を作る。計算された相関画 像に対して，ある間值を持って 2 值化し，粒子画像を ピックアップする。ここでは，粒子マスクとして 2 次元 のガウス分布を仮定している。

PMC法の利点を以下に示す。

(1)粒子マスクとの相関を取るため, 輝度の低い 粒子画像 でも，ガウス分布に近い形をしていれば，高い相関 值を取り，粒子画像をピックアップすることができ る。例えば，シート光から少しはずれた暗い粒子画 像は, 通常の輝度值による 2 值化ではピックアップ できないが，PMC法ではピックアップ可能である。

(2) 粒子画像が近づきすぎる上団子状になり，通常の 2 值化では分離が困難になる。粒子マスク相関法では, 中心輝度が等しければ，粒子間距離が粒子直径の場 合まで分離が可能である。

(3) 水槽端やセンサーの支持棒などの線形画像は，輝度 が高くても粒子マスクとの相関値は低くなるため自 動的に消去できる。

以上の $2 つ の$ 方法をSuper-Resolution 法のPTV部分に 適用する。PMC法についてはそのまま適用が可能である が，KC法については若干修正が必要である。KC法は時 系列デー夕を対象としているので，初期值をある程度粗 く与えても，数ステップ追跡すれば，誤対応の確率は低 くなる。しかし，2時刻の画像中で対応付けを行った場 合, 一度, 間違って対応付けしてしまえば修正ができな い。この問題を解決するため, 以下の方法を用いた。

PMC法によりピックアップされた第 1 時刻の粒子の 流速を，格子点流速場データから内挿する。内挿された 情報を基に，カルマンフィルターにより第 2 時刻の粒子 情報を推定する。推定された粒子と実測の粒子との対応 付けを $\chi^{2}$ 検定により行う。この段階までは通常のKC法 である。この段階では，誤対応のベクトルも含まれてい る場合が多い。各々のベクトル位置を中心に周囲の観測 


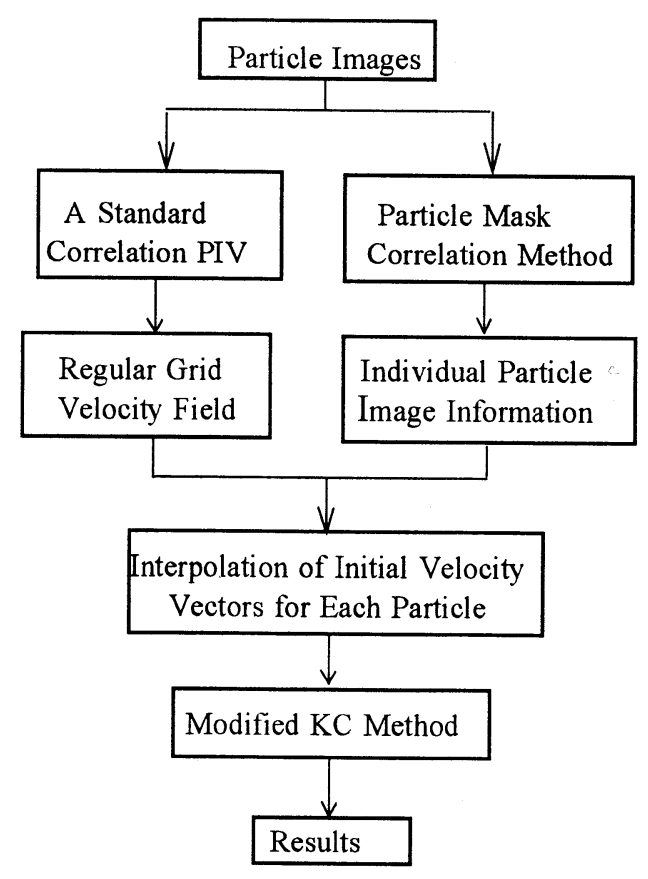

図-1 Super-Resolution KC法のフローチャート ベクトルから空間平均を求め, 対象としている観測べク トルと置き換える。これにより, 誤対応べクトルの影響 を小さくする。その後, KC法を再度適用し, 対応付け を行う。対応付けべクトル数が最大になるまで繰り返す。

Super-Resolution KC法の手順を以下に示す。また, 図1にフローチャートを示す。

(1) 2 時刻の画像より, 標準相関法を用いて粗な格子点上 の流速ベクトルを求める。

(2)PMC法により画像から粒子画像をピックアップする。

(3)ピックアップされた粒子の流速を，(1)で求めた格子点 上の流速ベクトルから内扱する。

(4)内挿された情報を元に, 第 1 時刻と第 2 時刻間の同一 粒子の対応付けをKC法により行う。

(5)対応付いた各観測ベクトルに対して，それぞれのベク トル位置を中心に，観測ベクトルの空間平均を取る。 その空間平均ベクトルを観測ベクトルと置き換える。

(6)再度, KC法による同一粒子の対応付け(4))を行う。

(7)上記(4)，(5)，(6)の手順を対応付け個数が最大になるま で繰り返す。

PMVにおける誤対応べクトルの除去には統計量を用 いた方法やニューラルネットワークを用いた方法等が提 案され，実用化されている。ここでは統計的手法を用い た誤ベクトル除去法を用いた。

\section{4. シミュレーション画像による性能評価}

Super-Resolution KC法の性能を評価するため, Keaneら 2)が用いたモンテカルロ・シミュレーション法による評 価と同様な評価を行った。 $5 \mathrm{~mm}$ (縦) $\times 5 \mathrm{~mm}$ (横) $\times$ $3 \mathrm{~mm}$ (奥)の領域に粒子密度 $\mathrm{N}_{\mathrm{I}}$ (=検索領域内の粒子個数)
で粒子を生成させた。粒子の位置はランダムに決定され た。シート光の厚さを $1 \mathrm{~mm}$ とし, トップハットな強度分 布を仮定し，奥行き方向中央部に照射した場合を考えた。 粒子サイズを画像上で直径8pixel と固定して作成した。 画像サイズは $1280 \times 1280$ pixelとした。

2 時刻間の粒子画像の移動は並進運動ばかりでなく, 乱れのモデルとして変動成分を新たに加え, 変動成分の 大きさ, サイズを変えて追跡精度を評価した。移動量は 次式で与えられた。

$$
\begin{aligned}
& \Delta x=\Delta x_{0}+a \cdot \sin \left(\frac{2 \pi x}{\lambda}\right) \sin \left(\frac{2 \pi y}{\lambda}\right) \\
& \Delta y=\Delta y_{0}+a \cdot \cos \left(\frac{2 \pi x}{\lambda}\right) \cos \left(\frac{2 \pi y}{\lambda}\right) \\
& \Delta l\left(=\sqrt{\Delta x_{0}^{2}+\Delta y_{0}^{2}}\right)
\end{aligned}
$$

今回は, 相関法の検索領域を $256 \times 256$ pixel とし， 2 時 刻間の粒子移動距離を25.6pixel とした。また, 変動成 分の振幅 $a$ については $0,0.1 \triangle l, 0.2 \triangle l, 0.3 \triangle l の 4$ ケース行った。振幅 $a=0$ の場合のみ, 移動距離 $d=25.6$,

51.2，76.8pixel と変化させた。また，変動成分の波長 $\lambda$

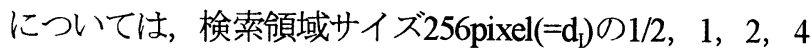
倍の 4 ケース変化させた。

図-2および図4は，縦軸に計測されたベクトル数に対 する正しく計測されたベクトル数の比(Probability of Success，正対応率)，横軸に粒子画像密度(Image Density) を取り，結果をプロットしたものである。得られた結果 を以下に示す。

（1）変動成分がない場合，全ての粒子画像密度，および 移動距離に対してほぼ 1 に近い值となり, 計測され たベクトルは全て正しく計測されている。Keaneらの 結果のように粒子密度による低下は見られない(図-2)。

(2) 変動成分の振幅 $a=0.1 \triangle l$ 場合も全ての粒子密度に 対して，ほぼ 1 に近い值をとる(図-4(a))。

(3) 変動成分の振幅 $a=0.2 \triangle l$ の場合, 变動波長 $\lambda=4 \mathrm{~d}_{\mathrm{l}}$, $2 \mathrm{~d}_{\mathrm{I}}$ で粒子密度が30個以上のとき, 正解率が 8 割以上 になる。変動波長 $\lambda=1 \mathrm{~d}_{1}, 1 / 2 \mathrm{~d}_{1}$ のケースでは全ての 粒子密度に対して正解率が 4 割以下である(図-4(b))。

(4) 変動成分の振幅 $a=0.3 \triangle l$ の場合, 変動波長 $\lambda=4 \mathrm{~d}_{\mathrm{r}}$ で 粒子密度が30（個／検索領域）以上のとき，8割以 上の正確さで追跡できる。変動波長 $\lambda=2 \mathrm{~d}_{\mathrm{I}}, 1 \mathrm{~d}_{\mathrm{I}}$, 1/2 $\mathrm{d}_{1}$ のケースでは，全ての粒子密度に対して正解率 は4割以下であった(図-4(c))。

(5) 変動成分の振幅 $a=0.2 \triangle l, 0.3 \triangle l$ の場合, 変動波長 の減少に伴い，正対応率は減少している。

図-3，および図-5は，縦軸に正しく計測されたベクト 儿密度, 横軸に粒子画像密度を取ったものである。図よ り得られた結果を以下に示す。

(1) 変動成分がない場合, および振幅 $a=0.1 \triangle l$ 場合, ほぼ全てのケースについて粒子密度と正しく計測され たベクトル密度は等しくなる(図-3)。つまり，画像中 


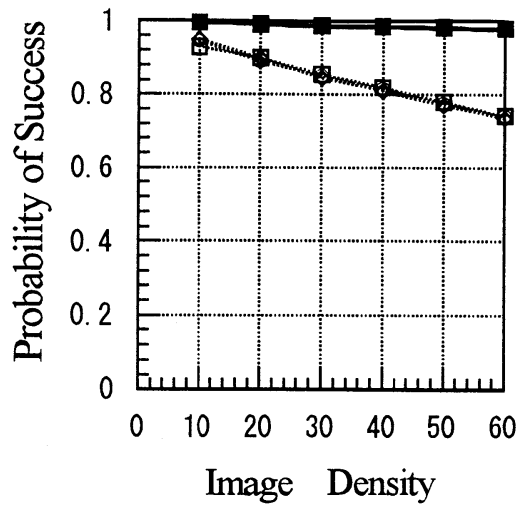

図-2 粒子画像密度 vs. 正対応率
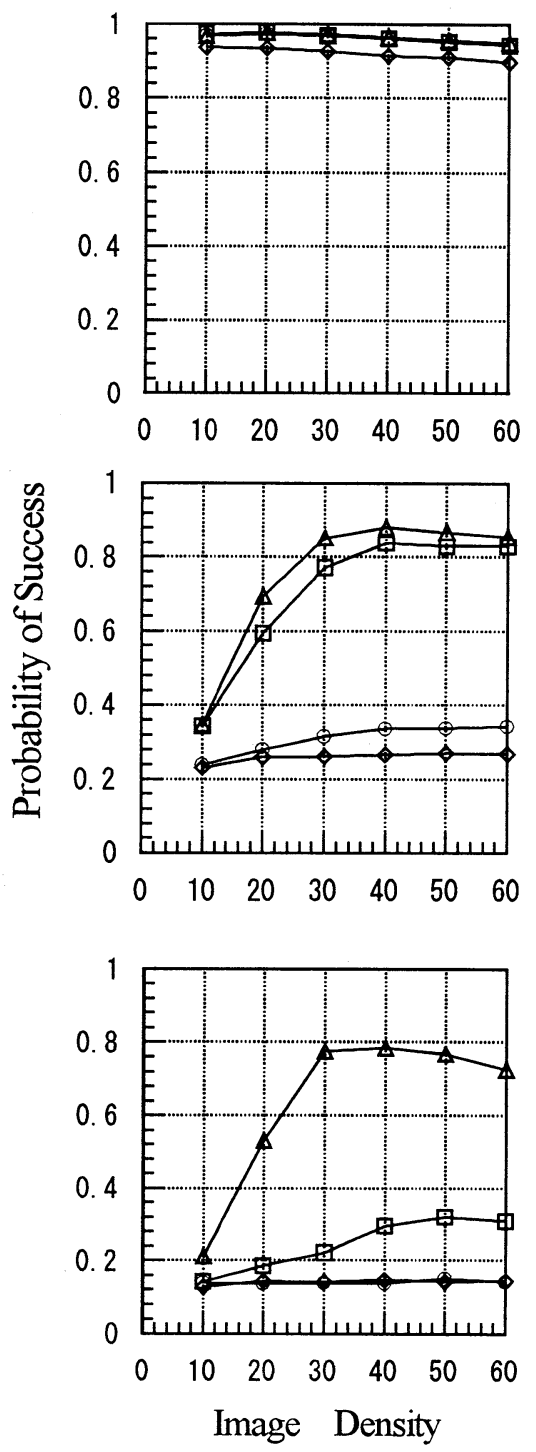

(a)

$\triangle=25.6$ pixel $a=0.1 \triangle$

$\diamond: \lambda=1 / 2 \mathrm{~d}_{1}$

$\mathrm{O}: \lambda=\mathrm{d}_{\mathrm{r}}$

$\square: \lambda=2 \mathrm{~d}_{\mathrm{I}}$

$\triangle: \lambda=2 \mathrm{~d}_{\mathrm{I}}$

(b)

$\triangle=25.6$ pixel $a=0.2 \triangle$

$\diamond: \lambda=1 / 2 \mathrm{~d}_{\mathrm{I}}$

$0: \lambda=d_{1}$

$\square: \lambda=2 \mathrm{~d}_{1}$

$\triangle: \lambda=4 \mathrm{~d}_{1}$

(c)

$\triangle l=25.6$ pixel

$a=0.3 \triangle$

$\diamond: \lambda=1 / 2 \mathrm{~d}_{\mathrm{f}}$

$O: \lambda=d_{1}$

$\square: \lambda=2 \mathrm{~d}_{\mathrm{I}}$

$\triangle: \lambda=4 \mathrm{~d}_{\mathrm{I}}$

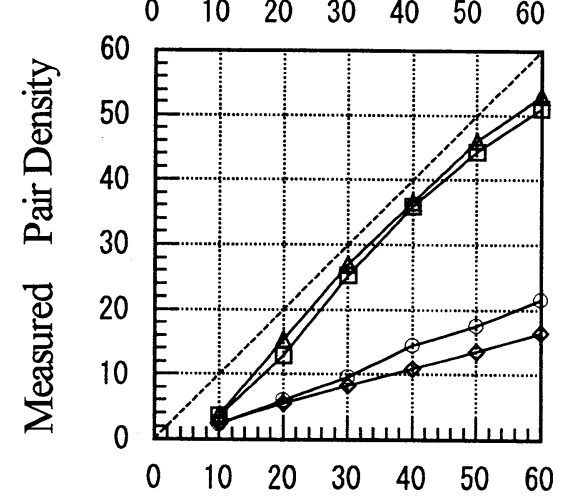

(The case of the sinusoidal motion added to the uniform displacement)

図-4 粒子画像密度 vs.正対応率
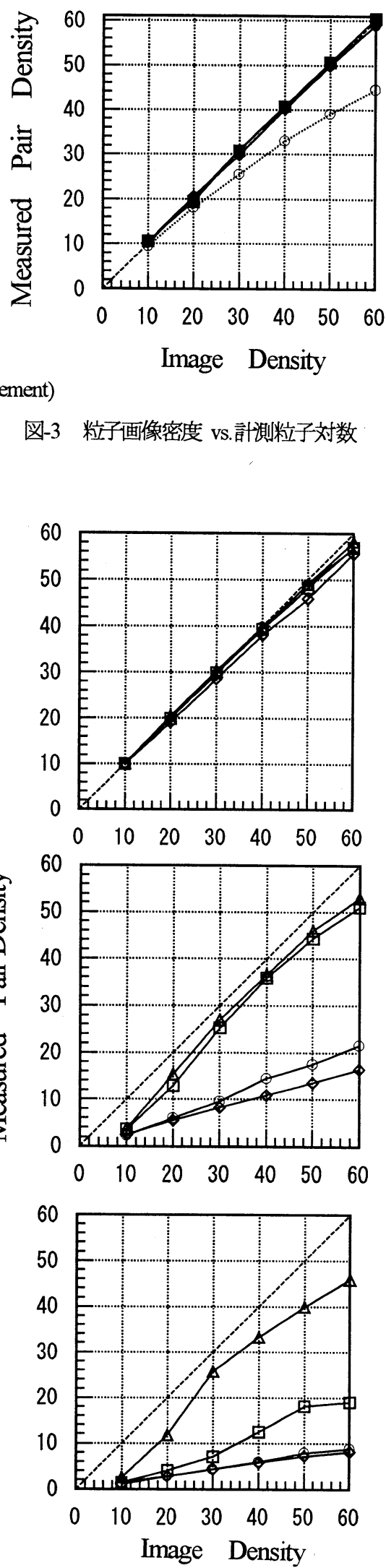

図-3 粒子画像密度 vs. 計測粒子対数

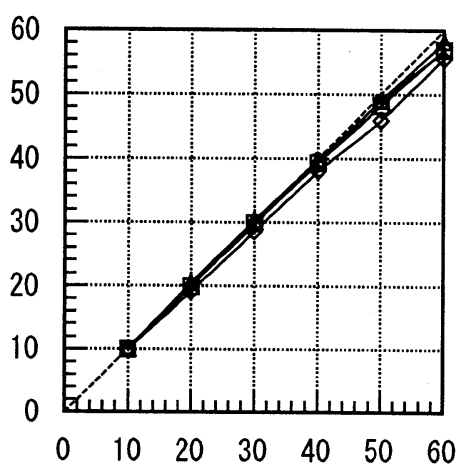

図-5 粒子画像密度 vs. 計測粒子対数 
にある全ての粒子が計測されている。

(2) 変動成分の振幅 $a=0.2 \Delta l$ の場合, および変動成分 の振幅 $a=0.3 \triangle l$ の場合, 図-2, および図-4の結果と 同様に粒子密度の減少および変動波長の減少に伴い, 正しく対応付いたベクトル密度は減少する(図-5)。

以上の結果より，今回行ったシミュレーションの条件 下では，変動成分の振幅が $0.1 \triangle l$ 以下の範囲では，ほぼ 全ての条件で正確に追跡することができることが分かっ た。また, 変動成分の振幅が $0.2 \triangle 1$ 場合でも, 変動波 長が検索領域サイズ以上で, かつ粒子密度が30（個／検 索領域）以上あれば80\%程度の正確さで追跡可能である。

\section{5. 適用例}

(1) Double-pulse/Single Image Case

Double-pulse/Single Image Caseとして，壁面境界層流 れ場の計測に適用した。解析には $4 \times 5$ インチのフィルム 画像を用いた。フィルム画像は，6つの領域に分割され， $522 \times 522$ pixelのデジタル C C Dカメラ(コダック社製) により、コンピュータに取り込まれた。図-6に6分割さ れたデジタル画像の 1 例を示す。照明には，ダブルパル スのレーザーライトシートを用い, 流れに平行な2次元 断面が撮影された。

図-7に計測結果を示す。図-7(a)は標準相関PIVにより 得られた格子点上の流速分布である。分割された各画像 の周辺部分はPIVの解析には用いていないので, 図中の 中央部には流速べクトルが存在しない。得られた流速べ クトル数は1802個であった。これを初期値として, Super-Resolution KC法により求めた結果が図-7(b)である。 図中の座標值が図-7(a)の値より 2 倍になっているが，こ れはPMC法により粒子位置を求めるときに画素間でも演 算を行っているためである。得られた流速べクトル数は 8479個であり，標準相関PIVに比べて約4.7倍の流速べク トル数が計測された。

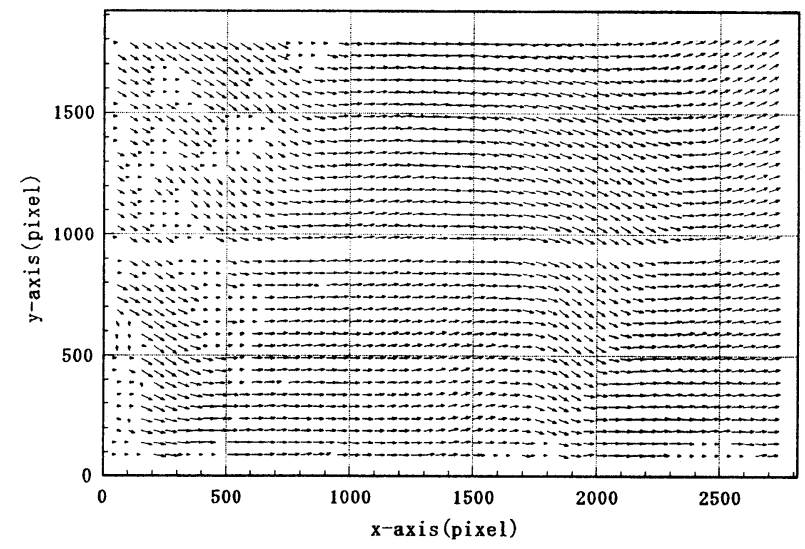

(a) 標準相関PIV法によって得られた流速分布
(2) Single-pulse/Double Image Case

Single-pulse/Double Image Caseとして, Rushton turbine 内の流れの画像解析を行った。解析に用いた画像は Sharpらわによって計測されたものである。計測には $1 \mathrm{k} \times$ $1 \mathrm{k}$ pixel のコリレーションカメラ(TSI製)を用い, SP/DF の画像を撮影した。照明には，ダブルパルスのNd:Yag レーザーを用い，シート光に広げ，2次元的に照明され た。撮影された画像はパーソナルコンピュータにデジタ 儿画像として取り込まれ，処理された。標準相関法のソ フトを用い，50\%重なりでスキャンニングし，格子点の 流速場を計測している。

図-8に計測結果を示す。図-8(a)は標準相関法により得 られた格子点上のベクトル分布図である。図-8(b)に今回 提案されたSuper-Resolution KC法を用いて計測した結果 を示す。図-8(b)は，図-7と同様の理由により，座標值が 図-8(a)の 2 倍になっている。図中の左部の空白部はター ビン翼の部分である。標準相関法により得られた格子点 流速ベクトルの数は3067であり, Super-Resolution KC法 により得られたベクトル数は9204であった。本手法が標 準相関法に比べ約3.0倍の流速べクトル数の計測が可能 となっている。図からわかるように，標準の相関法の計

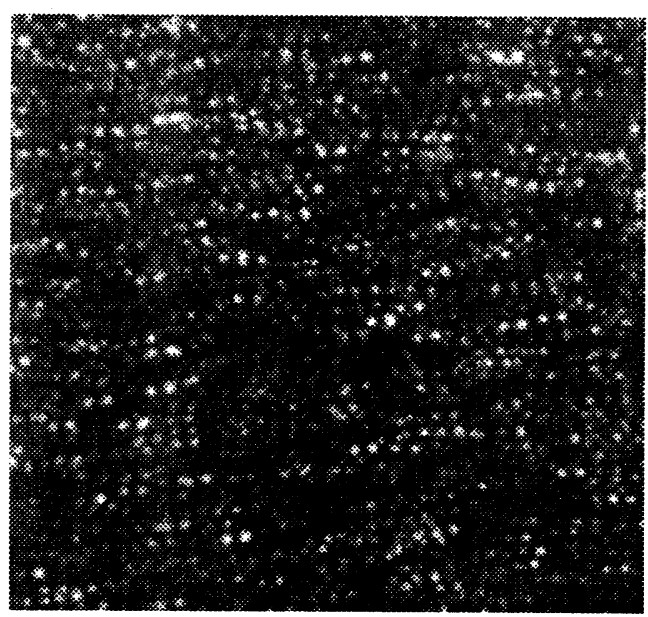

図-6 6分割された画像の 1 例(Double-pulse/Single-Image)

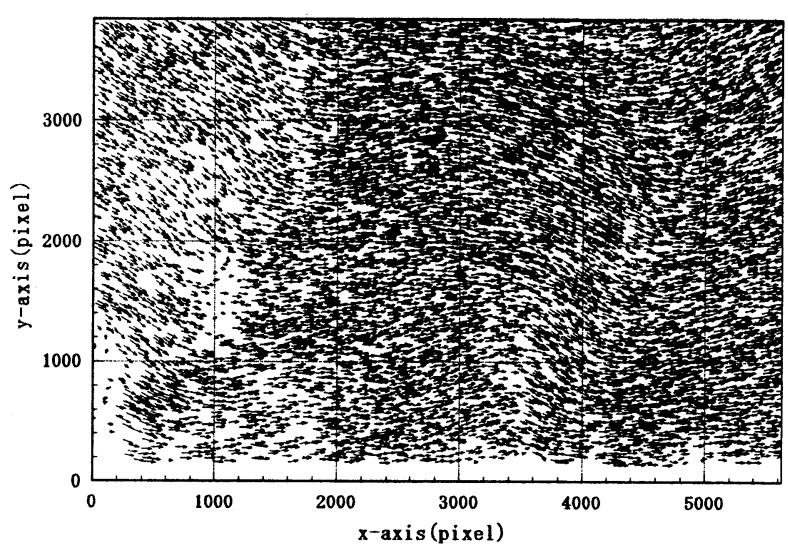

(b)Super-Resolution KC法によって得られた流速分布

図-7 Double-pulse/Single Image Caseの流れ場計測結果 


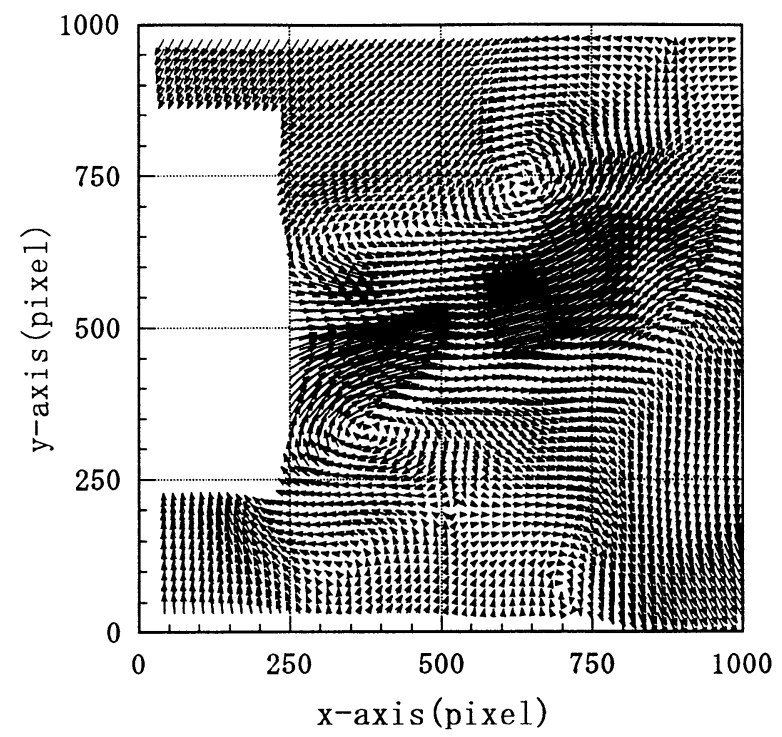

(a) 標準相関PIV法によって得られた流速分布

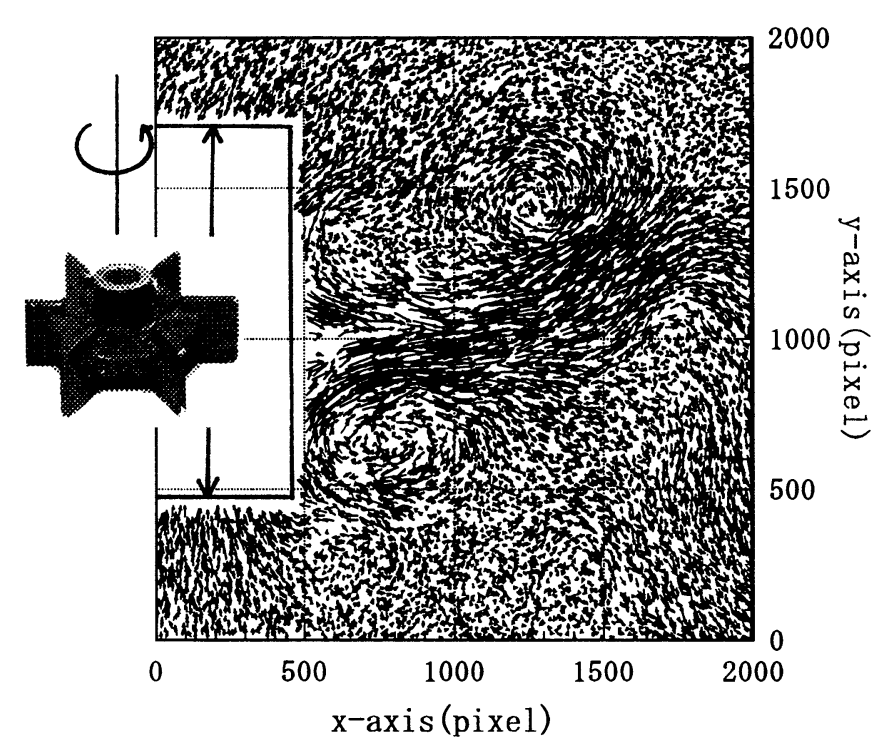

(b)Super-Resolution KC法によって得られた流速分布

図-8 Single-pulse/Double Image Caseの流孔場計測結果(Rushton turbine flow)

測結果に比べ, Super-Resolution KC法による計測結果の 方が小さな渦構造を計測できているのがわかる。

今回解析を行ったRushton turbine内の流れは 3 次元性 の強い流れであり, シート光を出入りする粒子が多くあ る。2次元性の強い流れ場の計測では, より解像度の高 い計測が期待される。

\section{6. 結言}

新しいSuper-Resolution PIVとして, Correlation PIV，カ ルマンフィルターと $x^{2}$ 検定による自動粒子追跡アルゴ リズム(KC法)，および粒子マスク相関(PMC)法を用いた Super-Resolution KC法を提案した。

シミュレーション画像を用いて，提案されたSuperResolution 法の性能を調查した。

模擬粒子画像が一様に移動するシミュレーションの結 果より，以下のことが分かった。

(1)移動距離が $0.1 \sim 0.3 \mathrm{~d}_{1}$ の範囲，および検索領域内粒子 画像密度が10〜60の範囲において，ほぼ全ての粒子画 像に対して正しく対応付けることができる。

(2)Keaneらの方法に比べて, 本論文で提案している手法 が大幅に改良されていることが明らかとなった。

また，模擬粒子の移動に波動成分が加わったケースの シミュレーション結果により，以下のことが分かった。

(3)変動成分の振幅が $0.1 \triangle l$ 以下の範囲では，ほぼ全ての 条件で正確に追跡できることが分かった。

(4)変動成分の振幅が $0.2 \Delta l$ 場合でも, 変動波長が検索 領域サイズ以上で，かつ粒子密度が30（個／検索領 域）以上あれば $80 \%$ 程度の正確さで追跡可能である。

(5)変動成分の振幅 $a=0.2 \Delta l, 0.3 \triangle l$ の場合, 変動波長 の減少に伴い，正対応率および計測粒子対数は減少し ている。
さらに，提案されたSuper-Resolution KC法は，実際の 流れ場の計測に適用された。Double-pulse/Single Image Case とSingle-pulse/Double Image Caseの 2 ケースの流れ場 について計測を行った。両ケースにおいて，標準相関 PIV法に比べて, Super-Resolution KC法による計測が3〜 5倍の流速ベクトル数を得ることができた。

\section{参考文献}

1) 例えば, Adrian, R. J., Christensen, K.T., Soloff, S.M. and Meinhart, C.D.: Decomposition of turbulent fields and visualization of vortices and turbulent momentum transport, Proc. of the $8^{\text {th }}$ Intl. Symp. on Flow Visualization, pp. 219.1-291.11, 1998.

2）江藤剛治: 土木技術者が作る超高速ビデオカメラ, 土木学会誌, pp.12-14, 1999.2

3) Keane, RD., Adrian, RJ. and Zhang, Y.: Super-resolution particle imaging velocimetry, Meas. Sci. Technol., 6, pp. 754-768, 1995.

4）江藤剛治，竹原幸生 : 多数のトレーサー粒子の自動 追跡のための新しいアルゴリズムの開発，水工学論 文集，Vol.34，pp.689-694, 1990.

5) 江藤剛治, 竹原幸生, 道奥康治, 久野悟志 : PTVの ための粒子画像抽出法に関する検討, 水工学論文集, Vol.40, pp.1051-1058, 1996.

6）江藤剛治，竹原幸生，岡本孝司: 標準画像を用いた 粒子マスク相関法とKC法の性能評価，日本機械学会 論文集(B編)，65巻633号，pp.184-191，1999.

7) Sharp, K.V., Kim, K.C. and Adrian, RJ.: Dissipation estimation around a Rushton turbine using particle image velocimetry, Proc. of the $9^{\text {th }}$ Intl. Symp. on Application of Laser Technique to Fluid Mech, 1998. 